\title{
Rubella vaccines: past, present and future
}

\author{
J. M. BEST \\ Department of Virology, United Medical and Dental Schools and Guy's \\ and St Thomas's Hospitals, St Thomas' Campus, Lambeth Palace Rd, \\ London SE1 \%EH
}

\section{THE PAST}

The association between rubella in pregnancy and congenital anomalies was first reported 50 years ago, by N. McAlister Gregg, an Australian ophthalmologist [1]. During the next 20 years his findings were confirmed by others (reviewed in [2]). However, the first reports of the isolation of rubella virus in cell cultures and development of tests for neutralizing antibodies were not published until 1962 $[3,4]$. Subsequent studies conducted in the UK and North America during a pandemic of rubella in 1963-4, were therefore able to make a more accurate estimate of the risks of maternal rubella at different stages of pregnancy. It was estimated that about 30000 rubella-damaged babies were born in the USA alone in 1963-4 [5]. This emphasized the importance of developing a vaccine to prevent infection in pregnancy and thereby, the birth of babies with rubella-induced congenital defects.

The main historical events associated with rubella and the development and use of rubella vaccines are listed in Table 1.

\section{Development of rubella vaccines}

Early attempts to produce an inactivated rubella vaccine were unsuccessful, as it was impossible to produce sufficient quantities of high titred virus in the cells of choice. Multiple inoculations of $10^{4}-10^{5}$ TCID50 of virus, inactivated with $\beta$ propiolactone, ultraviolet light or irradiation were required to elicit an antibody response in monkeys [6]. Studies on inactivated vaccines were discontinued when it was reported that rubella virus could be attenuated by multiple passage in cell cultures.

The first attenuated strain of rubella virus was produced by passaging rubella virus, isolated in 1961 from a US military recruit (M33), 77 times in vervet monkey kidney cell cultures to give the prototype vaccine HPV77 (high-passage virus-77) [7]. This attenuated strain was given a further five passages in duck embryo fibroblasts, since avian cells are less likely to carry extraneous agents than monkey kidney cells [8, 9]. This strain, HPV77. DE5, was licensed for use in the USA and many countries in Europe in 1969-70. The HPV77. DK12 vaccine strain was produced by passing HPV77 12 times in dog kidney cell cultures [10]. Although it was licensed in 1969 , its use was discontinued, as the incidence of adverse reactions was unacceptably high $[11,12]$.

A number of other attenuated strains have been developed (Table 2). The Cendehill strain was licensed for use in the USA in 1969 and in the UK and other 
Table 1. Main historical events

First report of congenital rubella [1]

Rubella virus isolated in cell cultures;

specific antibodies measured by neutralization test

Pandemic of rubella; 30000 cases of congenital rubella

$1963 / 4$ reported in the USA

Attenuated strains of rubella developed and first vaccine

$1965 / 7$

trials

HPV77. DE5 and Cendehill vaccine strains licensed in the USA

1969

Cendehill vaccine strain licensed in the UK

1970

MMR1* licensed in the USA

1971

RA27/3 vaccine strain licensed in the UK

1972

RA27/3 replaced HPV77. DE5 vaccine strain in the USA

1979

MMR+ licensed in the UK

1988

* MMR1 contained measles virus (Moraten strain), mumps virus (Jeryl Lynn strain) and rubella virus (HPV77. DE5 strain).

† MMR vaccines licensed in the UK contain measles virus (Schwartz strain), mumps virus (Urabe AM/9 or Jeryl Lynn strains) and rubella virus (RA27/3 strain).

European countries in 1970. This virus was isolated from a case of postnatally acquired rubella in 1963 at the University of Louvain, Belgium. It was attenuated by 51 passages in primary rabbit kidney cell cultures, derived from a select colony of rabbits bred and reared under pathogen-free conditions, which were shown to be free of adventitious agents $[13,14]$. A reliable index of attenuation was the inability of the attenuated strain to induce an antibody response in rabbits [15].

The Cendehill strain has been widely used in the USA and Europe, especially for adult women, as it is less reactogenic than the HPV77. DE5 and RA27/3 vaccine strains $[16,17]$.

The $\mathrm{RA} 27 / 3$ vaccine strain was isolated directly in human diploid fibroblasts (WI-38) from explant cultures established from a kidney of a rubella-infected fetus and attenuated by $27-30$ passages in WI-38 fibroblasts at temperatures between 30 and $35^{\circ} \mathrm{C}$. The name RA27/3 is derived from 'rubella abortus, 27 th specimen, third explant' [18].

Four other attenuated strains of rubella virus have been developed and are used in Japan (Table 2) $[19,20]$. The BRD-2 vaccine strain has been developed at the National Vaccine and Serum Institute in Beijing, China [21].

\section{Early vaccine trials}

The aim of the first vaccine trials was to assess reactogenicity and immunogenicity and also to determine whether virus was transmitted to susceptible contacts. This was of considerable importance, as transmission to susceptible pregnant contacts had to be avoided, since it was not known whether the attenuated strains would cause congenital defects if acquired in early pregnancy. Rhesus monkeys were used for the first experimental trials of rubella vaccine strains, because the pattern of virus excretion and antibody responses were similar to those observed in humans [22]. Following parenteral administration, the HPV77 strain was shown to induce neutralizing antibody responses which were comparable to those observed following administration of a low 


\section{Table 2. Attenuated rubella virus vaccine strains}

Vaccine

HPV77

HPV77.DE5

Cendehill

RA27/3

DCRB 19

KRT

$\mathrm{MEQ}_{11}$

TO-336

SK

BRD-2
Strain derivation

Army recruit with rubella (1961)

As above

Urine from a case of postnatally acquired rubella (1963)

Kidney of rubella-infected fetus (1964)

Throat swab from patient in Tokyo (1967)

Throat swab from patient in Matsue city (1968) -

Takahashi (MAT) strain

Throat washing from patient in Osaka (1966) -

Matsuura strain

Pharyngeal secretion from child with postnatally acquired rubella, Toyama, Japan (1967)

Throat washing from patient in Kumamato (1969) -

Matsuba strain

Child with postnatally acquired rubella in China (1980)

2BS strain
Attenuation
VMK (77)*

VMK (77);

duck embryo (5)

VMK (3)

primary rabbit kidney (51)

Human embryonic kidney (4);

WI-38 fibroblasts (17-25)

VMK (1); bovine kidney (53);

rabbit kidney (3)

VMK (4); primary rabbit testicle (36), primary

rabbit kidney (1)

VMK (14); Chick amnion (65); quail embryo fibroblast cells (11)

VMK (7); primary

guinea-pig kidney (20);

primary rabbit kidney (3)

VMK (1); swine kidney (60);

rabbit kidney (6)

Human diploid cells (30)

VMK, vervet monkey kidney.

* Number of passages in parentheses.

passage strain of virus. Monkeys given the attenuated strain did not transmit infection to susceptible cage contacts and when challenged by the intramuscular or intravenous route with a non-attenuated virus, they were protected from reinfection. The attenuated Cendehill strain was less immunogenic than the virulent virus when inoculated subcutaneously (SC) into monkeys and not infectious when inoculated intranasally (IN) [15]. Attenuation of RA27/3 was tested by inoculating human volunteers with different passage levels of the virus [23].

Trials were then carried out in institutional communities, in order to confirm immunogenicity and lack of significant reactogenicity and transmissibility following subcutaneous administration of vaccine. Trials were carried out in adults living in religious communities, prisoners, children living in institutions and boarding schools, mother and baby pairs, husband and wife, and children in families living in isolated conditions $[16,17,24]$. The lack of transmission to susceptible contacts may be due to a reduction in virus replication or to low infectivity, as virus is shed in the nasopharynx from approximately day 7 to day 25 after immunization [25, 26].

Once it had been established that transmission to susceptible contacts did not occur, more extensive trials were conducted in 'open' communities, which confirmed that the attenuated virus strains were safe and effective and that seroconversion occurred in $>95 \%$ of susceptible vaccinees $[16,17]$. It was also 
shown that rubella could be successfully combined with measles and mumps to give a triple vaccine, which induced antibodies to all three viruses [27, 28].

\section{THE PRESENT}

\section{Vaccines available}

The RA27/3 strain is now the most widely used rubella vaccine strain [20]. It replaced the HPV77. DE5 strain in the USA in 1979, since it was considered that the antibody response and protection afforded by this strain more closely resembled that induced by naturally-acquired infection than that induced by the other attenuated strains. The RA27/3 strain is included in MMR (measles, mumps and rubella) vaccines produced in the USA and western Europe. Other vaccine strains are used in Japan and China (Table 2).

\section{Administration of rubella vaccines}

Rubella vaccines are usually administered subcutaneously in a $0.5 \mathrm{ml}$ volume containing no less than 1000 TCID50 rubella virus. Before reconstitution, rubella (and MMR) vaccines must be stored at temperatures of $2-8{ }^{\circ} \mathrm{C}$ or lower and must be protected from light, which may inactivate the virus. They must be transported at $10^{\circ} \mathrm{C}$ or below or on dry ice. Reconstituted vaccine should be discarded if not used within $1 \mathrm{~h}$.

The RA27/3 strain, unlike Cendehill and HPV77. DE5, will induce an immune response when at least 1000 TCID50 is administered IN; it is not transmitted to susceptible contacts $[23,29]$. The IN route is not considered suitable for routine use, however, as the vaccinator must be experienced and the recipient must be cooperative and free from respiratory infection and obstruction [30].

\section{Contraindications}

It is recommended that rubella vaccine should not be given to patients whose immunological response is impaired, as a result of disease or treatment with immunosuppressive drugs. However, there are no reports of adverse events in such persons. Rubella vaccine should not be given within 3 weeks of another live vaccine or BCG. Passively acquired antibodies may interfere with the immune response and immunization should therefore be delayed for about 3 months after a blood transfusion or a dose of human immunoglobulin. Although recent administration of anti-D immune globulin is not a contraindication to postpartum immunization, it is advisable to confirm seroconversion 8-12 weeks later. Pregnancy is an absolute contraindication to immunization, since the vaccine strains may be transmitted transplacentally (see below). In the UK it is recommended that pregnancy should be avoided for 1 month after rubella or MMR immunization [31], while in the USA an interval of 3 months is recommended [32]. Thus, the vaccinator should ensure that effective contraceptive precautions are being taken before immunizing susceptible women of childbearing age.

Contraindications to rubella immunization have been discussed in more detail elsewhere [31-33]. 


\section{Adverse reactions}

Rubella vaccines are generally very well tolerated. Adverse reactions may occur but are less severe than those experienced following naturally-acquired infection and are more likely to occur in adults than in children. Lymphadenopathy, fever, rash, arthralgia (painful joints) or arthritis (joint swelling or limitation of movement) may occur between 10 days and 4 weeks after immunization of susceptibles. The onset of joint symptoms is usually between 13 and 21 days after immunization, a few days after the appearance of lymphadenopathy or rash; they persist for between 1 day and 3 weeks. Lymphodenopathy may not be noticed, but occasional vaccinees complain of enlarged and tender lymph nodes. Rash may occur in up to $25 \%$ RA27/3 vaccinees (Table 3 ), but is usually faint, macular and fleeting. There have been very occasional reports of transient peripheral neuritic complaints, such as paresthesias and pain in the arms and legs [34]. Petechial or purpuric rashes are not seen after rubella immunization, but mild thrombocytopenia has been recorded following immunization with RA27/3 and Cendehill $[35,36]$.

Joint symptoms, which may occur in up to $52 \%$ adult women with naturallyacquired rubella [37], are less frequent and less severe following immunization. The peripheral joints, i.e. knees, finger joints, wrists and ankles, are most frequently affected, but symptoms are generally mild and seldom result in time lost from work [25, 37]. The incidence of joint symptoms following both natural infection and immunization of susceptibles increases with age $[25,38]$. Weibel and colleagues [38] observed that joint symptoms occurred in $7.5 \%$ persons aged 12-25 and in 58.3\% of those aged 26-41 following immunization with HPV77. DE5. Best and her colleagues [25] reported that joint symptoms occurred more frequently in HPV77. DE5 vaccinees $(38.7 \%)$ and RA27/3 vaccinees $(41.7 \%)$ than in Cendehill $(22.9 \%)$ and TO-336 $(17.6 \%)$ vaccinees. Overall, joint symptoms lasting 7 days or more were seen in 5 of $136(3.7 \%)$ vaccinees. Tingle and his colleagues [37] reported recurrent arthropathy for longer than 18 months in 2 of 44 adult females given RA27/3. Joint reactions with HPV77-derived vaccines tend to be more severe. The HPV77. DK12 vaccine, although licensed in the USA in 1969, was soon withdrawn, as it induced particularly severe joint reactions, even in children, some of whom experienced an intermittent arthritis for up to 3 years [11, 12].

It has been suggested that joint symptoms may result from infection of synovial cells, from the formation of immune complexes or to an autoimmune reaction. Rubella virus has been isolated from joint aspirates from vaccinees with vaccine-induced arthritis $[39,40]$ and both wild and attenuated strains of rubella will replicate in human synovial cell cultures $[41,42]$. Studies of immune complexes in the serum of vaccinees with joint symptoms have yielded conflicting results [43-45]. However, if virus persists in synovial cells [40] and rubellaspecific antibodies are produced in joints [46], it is possible that immune complexes could be produced locally in the joints.

Hormonal factors may also play a role in the development of joint symptoms. Joint symptoms do not usually occur in pre-pubertal girls [17] and occur less frequently in men [37] and in women vaccinated in the immediate post-partum 
Table 3. Vaccine-associated reactions following vaccination with the RA27/3 vaccine strain [25]

$\begin{array}{lcc} & \text { RA27/3 } & \text { Controls* } \\ \text { Number } & 36 & 39 \\ \text { Lymphadenopathy } & 16(44 \%) & 14(35 \%) \\ \text { Rubelliform rash } & 9(25 \%) & 1(2 \%) \\ \text { Joint symptoms } & 15(42 \%) & 0\end{array}$

* Unvaccinated persons of the same age range followed up over a 30-day period.

period [47]. Swartz and colleagues [48] showed that joint symptoms were less likely to occur in those vaccinated 6-24 days after onset of menstruation than in those vaccinated within 5 days of the onset of menstruation. In contrast, Best and her colleagues [25] showed that joint symptoms were most likely to occur within 7 days of the onset of menstruation and were unrelated to the use of oral contraceptives. They suggested that it should be possible to reduce the incidence of joint symptoms by vaccinating women in the last 7 days of their cycle. No association with the HLA antigens of the A and B loci was observed [26].

It has been suggested that rubella virus is a possible cause of chronic inflammatory joint disease. The virus has been isolated from the peripheral blood lymphocytes (PBLs) from a small number of adult women with joint symptoms persisting for a few years after rubella immunization or natural infection by a group working in British Columbia [49, 50]. They also isolated rubella virus from PBLs and synovial fluid mononuclear cells from 7 of $19(35 \%)$ children with chronic inflammatory joint disease [51]. These results have not been confirmed by others, but it is possible that they may be explained by the persistence of rubella virus in circulating lymphocytes or in the joints. Further evidence for the possible persistance of rubella virus comes from the detection of rubella-specific IgM responses for up to 4 years after immunization ([52], S. O'Shea, J. M. Best and J. E. Banatvala, unpublished results).

\section{Risks of vaccination in pregnancy}

Rubella vaccination is contraindicated during pregnancy because it has been shown that the virus will cross the placenta following vaccination (reviewed in [53]). However, when 514 susceptible women inadvertently immunized within 3 months of conception or during pregnancy, who elected to go to term, were followed up, there was no evidence of congenital abnormalities compatible with congenital rubella among their infants, although 9 of 400 babies tested had evidence of congenital infection (Table 4) [32,53], G. Enders, personal communication; P. Tookey, personal communication; M. L. Lindegren, personal communication). However, 94 of the 324 women in the US study had received the HPV77. DE5 or Cendehill vaccine strains, which are no longer in use (see Vaccines available, p. 22). The Rubella Vaccination in Pregnancy Study is continuing to collect data in the UK on the risks of vaccination in pregnancy, although the study in the USA has been discontinued. Although pregnancy is a contraindication for vaccination, vaccination is not normally a reason for termination of pregnancy, although the decision should be left to the patient and her obstetrician. However, it should be noted that in the US studies, only about a third of the women followed 
Table 4. Combined data for risk of CRS in infants born to susceptible women whose pregnancies were complicated by rubella immunization

Live births to women receiving rubella immunization

\begin{tabular}{|c|c|c|c|c|}
\hline Country & $\begin{array}{l}\text { Within } 3 \text { months } \\
\text { of conception or } \\
\text { during pregnancy }\end{array}$ & $\begin{array}{c}\text { Between } 1 \text { week } \\
\text { before and } 4 \\
\text { weeks after } \\
\text { conception }\end{array}$ & $\begin{array}{l}\text { Evidence of } \\
\text { infection }\end{array}$ & $\begin{array}{l}\text { Abnormalities } \\
\text { compatible } \\
\text { with CRS }\end{array}$ \\
\hline $\begin{array}{l}\text { USA } \\
\text { Federal } \\
\text { Republic of } \\
\text { Germany }\end{array}$ & $\begin{array}{l}321 \\
144\end{array}$ & $\begin{array}{l}113 / 312(36 \%) \\
\text { NK }\end{array}$ & $\begin{array}{l}6 / 222(2 \cdot 7 \%) \\
3 / 144(2 \cdot 1 \%)\end{array}$ & $\begin{array}{l}0 / 324 \\
0 / 144\end{array}$ \\
\hline $\begin{array}{l}\text { Sweden } \\
\text { UK }\end{array}$ & $\begin{array}{r}5 \\
45\end{array}$ & $\begin{array}{l}\text { NK } \\
9 / 45(20 \%)\end{array}$ & $\begin{array}{l}0 / 5 \\
1 / 30(3 \cdot 3 \%)\end{array}$ & $\begin{array}{c}0 / 5 \\
0 / 42\end{array}$ \\
\hline Totals & 515 & $122 / 357(34 \%)$ & $10 / 401(2.5 \%)$ & $0 / 515$ \\
\hline
\end{tabular}

up were vaccinated in the high risk period between 1 week before to 4 weeks after conception (Table 4) $[32,54]$. The estimated risk of major malformations attributable to $\mathrm{RA} 27 / 3$ vaccine is between 0 and $1.6 \%$, based on the binomial distribution with $95 \%$ confidence limits $[32,54]$, which is less than the risk of major malformation in unselected pregnancies $(2-3 \%)$. The observed risk with all vaccine strains to date is zero.

Most adult women who are vaccinated have been screened and shown to be susceptible to rubella. However, in cases where the woman has not been tested, it is often possible to determine her immune status retrospectively, by testing a serum sample taken within 8 weeks of immunization for rubella-specific IgM, which can usually be detected if there was no prior immunity $[55,56]$.

\section{Immune responses}

In seronegative vaccinees. Vaccine trials have shown that all licensed rubella vaccines induce an antibody response $[16,17]$. Haemagglutination inhibition (HAI) antibodies usually develop between 10 and 28 days after vaccination [57-59], although a response may occasionally be delayed. HAI antibodies are usually 4- 8-fold lower in vaccinees than following natural infection. The RA27/3 strain induces antibodies which most closely resemble those resulting from natural infection $[59,60]$. Cusi and colleagues $[61,62]$ found that antibodies specific for all three structural proteins, E1, E2 and C, could be detected in sera taken 1 month after immunization with RA27/3, but only antibodies to E1 of wild-type virus were found to persist for 3 years or more in all eight vaccinees tested.

About $5 \%$ of vaccinees fail to seroconvert [16, 17]. Failure to seroconvert may be due to a concurrent infection and such persons will respond when revaccinated. Some women who apparently fail to seroconvert may have a low level of preexisting antibody, which was not detected by the screening test used. Such women should be retested by more sensitive assays, such as enzyme immunoassay (EIA) or latex agglutination (LA) (see below).

Studies on the long-term persistance of vaccine-induced antibodies have shown that immunity is probably lifelong in most vaccinees; antibodies have been 
detected in 2066 of $2154(95.9 \%)$ vaccinees who were tested between 9 and 21 years after immunization (Table 5). These results, however, are influenced by the sensitivity of the techniques used to measure rubella antibodies. Horstmann and her colleagues [64] reported $16 \%$ of HPV77. DE5 vaccinees were seronegative by HAI 11-12 years after immunization. However, HAI is a relatively insensitive technique and studies which have used several different techniques, including EIA and LA, have found that a smaller percentage of vaccinees were seronegative $[66,68,70]$. Although $O^{\prime}$ 'Shea and colleagues [66], working in the UK, showed that $96 \%$ of 117 vaccinees had antibodies $>15 \mathrm{i} . \mathrm{u} . / \mathrm{ml}$ when tested $10-21$ years after immunization by single radial haemolysis (SRH), EIA and LA, $10 \%$ of their vaccinees had antibody concentrations $<15$ i.u. $/ \mathrm{ml}$ when tested 5-8 years after immunization [71]. The increase in seropositivity seen suggests that reinfection had boosted antibody concentrations, as rubella virus continued to circulate in the UK at that time. A study conducted in schoolchildren in Massachusetts, where rubella had been virtually eliminated, revealed that $8.7 \%$ of children given HPV77. DE5 10-14 years earlier had antibody concentrations below 7 i.u. $/ \mathrm{ml}$ [70]. In general, Cendehill and HPV77. DE5 vaccinees are more likely to have low antibody concentrations, become seronegative and exhibit booster antibody responses than $R A 27 / 3$ vaccinees $[65,66]$, which is why the $R A 27 / 3$ vaccine strain is now the most widely used.

Rubella-specific IgM can be detected in serum of most vaccinees between 3 and 8 weeks after immunization if sensitive techniques are employed [56, 57, 59]. Using an M-antibody capture radioimmunoassay (MACRIA), low levels of IgM antibodies have been detected in 18 of $53(33.9 \%)$ vaccinees 1 year after immunization [52] and in 7 of the 18, 3 years after immunization (S. O'Shea, J. M. Best and J. E. Banatvala, unpublished results).

Rubella-specific IgA can be detected in both the serum and nasopharyngeal secretions following administration of all vaccine strains, as well as after naturally acquired infection $[59,72,73]$ and may persist in the serum for 10-12 years after immunization [59]. In the serum there is apparently a transient oligomeric (10S) IgA response [74] and a persistent $7 \mathrm{~S} \operatorname{IgA}$ response [59]. Nasopharyngeal $\operatorname{IgA}$ antibodies have been detected in $80 \%$ of vaccinees 6 weeks after immunization [59]. The highest concentrations were seen in vaccinees given $\mathrm{RA} 27 / 3, \mathrm{SC}$ or IN. Nasopharyngeal IgA antibodies persisted in RA27/3 vaccinees for up to 5 years, but for only $2-3$ years after immunization with the Cendehill, HPV77. DE5 and TO-336 strains [59].

There have been few studies on cell mediated immune responses to rubella virus. Lymphocyte transformation responses are lower after immunization than after naturally-acquired infection and may be difficult to detect [75-77].

In seropositive vaccinees. Not all those with low levels of antibody will develop booster responses after immunization with RA27/3 [52, 78, 79]. Vãåna̋nen and his colleagues [80] reported only a small increase in antibody titre in persons with low levels of antibody, while $28 \%$ had no increase in titre as measured by SRH. Some subjects exhibit only a transient rise in antibody concentration $[81,82]$. In the UK it is current practice to vaccinate women with rubella antibodies $<15 \mathrm{i} . \mathrm{u} . / \mathrm{ml}$. The PHLS Working Party on the Laboratory Diagnosis of Rubella [83] recommended that revaccination of women with a documented history of two or 
Table 5. Persistence of antibodies 9-21 years after immunization of seronegative persons - comparison of four vaccines

\begin{tabular}{|c|c|c|c|}
\hline Vaccine & $\begin{array}{c}\text { No. seronegative/ } \\
\text { no. tested } \\
\text { (\% seronegative) }\end{array}$ & $\begin{array}{l}\text { Years after } \\
\text { vaccination }\end{array}$ & Authors \\
\hline $\mathrm{RA} 27 / 3$ & $\begin{array}{l}1 / 94(1 \%) \\
1 / 21(4 \cdot 7 \%) \\
0 / 35 \\
0 / 115 \\
1 / 48(2 \cdot 1 \%)\end{array}$ & $\begin{array}{l}12 \\
15 \\
11 \\
14 \\
10-21\end{array}$ & $\begin{array}{l}\text { H. Zealley and E. Edmund* } \\
\text { Hillary and Griffith [63] } \\
\text { Horstmann et al. [64] } \\
\text { Enders and Nickerl [65] } \\
\text { O'Shea et al. [66] }\end{array}$ \\
\hline Total & $3 / 313(1 \%)$ & $10-21$ & \\
\hline Cendehill & $\begin{array}{c}3 / 145(2 \%) \\
3 / 319(1 \%) \\
18 \dagger / 400(4.5 \%) \\
2 / 102(2 \%) \\
1 \ddagger / 40(2.5 \%)\end{array}$ & $\begin{array}{l}12 \\
15 \\
16 \\
14-17 \\
10-21\end{array}$ & $\begin{array}{l}\text { H. Zealley and E. Edmund* } \\
\text { Just et al. [67] } \\
\text { Chu et al. [68] } \\
\text { Enders and Nickerl [65] } \\
\text { O'Shea et al. [66] }\end{array}$ \\
\hline Total & $27 / 1006(2 \cdot 7 \%)$ & $10-21$ & \\
\hline TO-336 & $\begin{array}{l}0 / 25 \\
0 / 11\end{array}$ & $\begin{array}{l}9 \\
12-13\end{array}$ & $\begin{array}{l}\text { Hoshino et al. [69] } \\
\text { O'Shea et al. [66] }\end{array}$ \\
\hline Total & $0 / 36$ & $9-13$ & \\
\hline HPV77.DE5 & $\begin{array}{c}13 / 79(16 \%) \\
26 \dagger / 302(8 \cdot 7 \%) \\
18 / 385(4 \cdot 7 \%) \\
0 / 15 \\
1 / 18(5 \cdot 5 \%)\end{array}$ & $\begin{array}{l}11-12 \\
10-14 \\
16 \\
14 \\
10-21\end{array}$ & $\begin{array}{l}\text { Horstmann et al. [64] } \\
\text { Orenstein et al. [70] } \\
\text { Chu et al.[68] } \\
\text { Enders and Nickerl [65] } \\
\text { O'Shea et al. [66] }\end{array}$ \\
\hline Total & $58 / 799(7 \cdot 3 \%)$ & $10-21$ & \\
\hline Total & $88 / 2154(4 \cdot 1 \%)$ & $9-21$ & \\
\hline
\end{tabular}

more rubella vaccinations was not necessary if rubella antibodies were detected by two different assays, even if antibody concentrations were $<15 \mathrm{i} . \mathrm{u} . / \mathrm{ml}$.

\section{Vaccine efficacy and reinfection}

Both natural infection and immunization provide protection from symptomatic reinfection, except in rare cases. However, asymptomatic reinfection, as demonstrated by a significant rise in antibody titre, may occur after prolonged exposure to a case of rubella or following experimental challenge. Specific IgM responses may also be detected if sensitive assays are used, but are generally lower and more transient than IgM responses seen in primary infection $[84,85]$. Experimental challenge studies have demonstrated that reinfection is more likely to occur in those with vaccine-induced immunity than in those whose immunity is naturally - acquired, and less likely to occur in $\mathrm{RA} 27 / 3$ vaccinees than in those vaccinated with HPV77. DE5 and Cendehill [26, 84].

Reinfection in the first trimester of pregnancy will not present a hazard to the developing fetus, unless it is accompanied by a viraemia. There is evidence from experimental studies that viraemia may occasionally occur following challenge. 
O'Shea and her colleagues [84] detected a viraemia in 1 of 19 vaccinees with a low level of pre-existing antibodies $(<15 \mathrm{i} . \mathrm{u} . / \mathrm{ml})$ following $\mathrm{IN}$ challenge with high titre RA27/3. Schiff and his colleagues [86] detected viraemia in 3 of 6 vaccinees with low or undetectable antibodies following IN challenge with a large dose (approximately 1000 TCID50) of an unattenuated strain of rubella virus. Although the majority of women who have experienced reinfection in pregnancy have delivered infants without evidence of congenital infection, there are a small number of well documented cases, where an infant with congenital rubella syndrome has been born to a woman who had rubella antibodies prior to the affected pregnancy [87-89]; some of these women had a history of vaccination. Studies are in progress to determine whether these women have a defect in their immune responses to rubella, such as a failure to mount a cell mediated immune response or lack of antibodies to the 'protective' epitope of the virus.

\section{THE FLTURE}

Although the attenuated rubella vaccines in use are efficacious and do not usually induce adverse reactions in children, the RA27/3 strain may induce joint symptoms in up to $42 \%$ of susceptible adult women following vaccination and a small proportion may have persistent or recurrent symptoms. In addition, the vaccine should not be given to pregnant women or to immunocompromised persons, as discussed above. It is probable that in the future it will be considered desirable to produce subunit vaccines, containing only the 'protective' epitopes of the virus, by recombinant techniques or as peptides [90]. Such techniques are already used to produce hepatitis $B$ vaccine and several other viral vaccines, which are currently being evaluated [91]. The 'protective' epitopes of rubella virus have not yet been identified, although three epitopes which react with HAI and neutralizing antibodies have been described on E1 [92,93]. No significant antigenic variation in the E1 glycoprotein was detected when nine strains of rubella were compared using a panel of 31 monoclonal antibodies [J. M. Best and colleagues, unpublished results]. However, experiments which compared the reactivity of sera from vaccinees with antigens prepared from wild-type and attenuated strains have suggested that antigenic differences may occur in E2 or C $[62,94,95]$. The rubella virus genome has been cloned and sequenced $[96]$ and the viral structural proteins (E1 and E2) have been expressed in Escherichia coli, COS cells and baculovirus [97-101, P. G. Sanders and J. M. Best, unpublished results]. It remains to be determined which expression system will be found to be most suitable for production of the viral polypeptides required to induce 'protective' antibodies. This will depend on the post transcriptional modification of the proteins required for immunogenicity in man and the ability to purify the proteins produced [90].

\section{REFERENCES}

1. Gregg NMcA. Congenital cataract following german measles in the mother. Trans Ophthal Soc Aust $1941 ; 3: 35-46$.

2. Banatvala JE, Best JM. Rubella. In: Collier LH, Timbury MC, eds. Topley and Wilson's principles of bacteriology, virology and immunity, vol. 4, 8th Ed. London: Edward Arnold, 1990, 501-31. 
3 Parkman PD, Buescher EL, Artenstein MS. Recovery of rubella virus from army recruits. Proc Soc Exp Biol Med. 1962; 111 : 225-30.

4 Weller TH, Neva FA. Propogation in tissue culture of cytopathic agents from patients with rubella-like illness. Proc Soc Exp Biol Med 1962; 111 : 215-25.

5 Cooper LZ. Congenital rubella in the United States. In: Krugman S, Gershon AA, eds. Infections of the fetus and the newborn infant, vol 3. New York: AR Liss, 1975, 1-21.

6 Beck ES. Review of studies with inactivated rubella virus. Am J Dis Child 1969 ; 118 : 328-33.

7 Parkman PD, Meyer HM, Kirschstein BL, Hopps HE. Attenuated rubella virus. I. Development and laboratory characterization. N Engl J Med 1966; 275 : 569-74.

8 Meyer HM, Parkman PD, Panos TC. Attenuated rubella virus. II. Production of an experimental live-virus vaccine and clinical trials. N Engl $J$ Med $1966 ; 275$ : 575-80.

9 Hilleman MR, Buynak EB, Whitman JE, Weibel RW, Stokes J. Live attenuated rubella virus vaccine. Experiments with duck embryo cell preparations. Am J Dis Child 1969; 118 : 116-71.

10 Parkman PD, Meyer HM. Prospects for a rubella virus vaccine. Progr Med Virol 1969 ; 11 : 80-106.

11 Spruance SL, Klock LE, Bailey A, Ward JR, Smith CB. Recurrent joint symptoms in children vaccinated with HPV77. DK12 rubella vaccine. J Pediatr $1972 ; 80$ : 413-7.

12 Thompson GR, Weiss JJ, Shillis JL, Brackett RG. Intermittent arthritis following rubella vaccination. Am J Dis Child $1973 ; 125$ : $526-30$.

13 Peetermans $J$, Huygelen C. Attenuation of rubella virus by serial passage in primary rabbit kidney cell cultures. I. Growth characteristics in vitro and product of experimental vaccines at different passage levels. Arch fur Virusforsch, 1967; 21 : 133-42.

14 Huygelen, C, Peetermans, J, Prinzie A. An attentuated rubella virus vaccine (Cendehill 51 Strain) grown in primary rabbit kidney cells. Archiv fur Virusforsch $1969 ; 11$ : 107-125.

15 Huygelen C, Peetermans J. Attenuation of rubella virus by serial passage in primary rabbit kidney cell cultures. II. Experiments in animals. Archiv fur Virusforsch 1967; 21 : 357-65.

16 Regamey RH, De Barbieri A, Hennessen W, Ikic D, Perkins FT (eds). International symposium on rubella vaccines, London. Symp Series Immunobiol Stand. Basel/New York: Karger, 1969.

17 Proceedings of the International Conference on Rubella Immunization. Am J Dis Child, $1969 ; 118$.

18 Plotkin SA, Farquhar J, Katz M, Ingalls TH. A new attenuated rubella virus grown in human fibroblasts : evidence for reduced nasopharyngeal excretion. Am J Epidemiol 1967; 86 : $468-77$.

19 Shishido A, Ohtawara M. Development of attenuated rubella virus vaccines in Japan. Jpn J Med Sci Biol 1976; 29 : 227-53.

20 Perkins FT. Licensed vaccines. Rev Infect Dis 1985; 7 (suppl 1): S73-6.

21 Yaru H, Zaho K, Yinxiang G, Sulan H, Shuzhen W, Changtai W. Persistance of vaccineinduced immune responses to rubella: comparison with natural infection. Rev Infect Dis 1985; 7 (suppl 1): S79.

22 Parkman PD, Phillips PE, Kirschstein RL, Meyer HM. Experimental rubella virus infection in the rhesus monkey. J Immunol 1965; 95 : 743-52.

23 Plotkin SA. Development of RA27/3 attenuated rubella virus grown in WI-38 cells. In: Regamey RH, De Barbieri A, Hennessen W, Ikic D, Perkins FT, eds. International symposium on rubella vaccines, London. Symp Series Immunobiol Stand. Basel/New York: Karger. 1969, 249-60.

24 Freestone DS. General Review of clinical trials of rubella vaccines. Postgrad Med J 1972; July suppl: $30-4$.

25 Best JM, Banatvala JE, Bowen JM. New Japanese rubella vaccine : comparative trials. Br Med J 1974; 3: 221-4.

26 Harcourt GC, Best JM, Banatvala JE. HLA antigens and responses to rubella vaccination. J Hyg 1975; 83 : 405-12.

27 Weibel RE, Buynak EB, McLean AA, Roehm RR, Hilleman MR. Persistance of antibody in human subjects for 7-10 years following administration of combined live attenuated measles, mumps and rubella virus vaccines. Proc Soc Exp Biol Med 1980; 165 : 260-3. 
28 Robertson CM, Bennett VJ, Jefferson N, Mayon-White RT. Serological evaluation of a measles, mumps and rubella vaccine. Arch Dis Child 1988; 63: 612-6.

29 Plotkin SA, Farquhar JD, Ogra PL. Immunologic properties of RA27/3 rubella vaccine. J Am Med Assoc 1973; 225 : 585-90.

30 Hillary IB. Trials of intranasally administered rubella vaccine. J Hyg 1971; 69: 547-52.

31 Department of Health. Immunization against infectious disease. London: HMSO, 1990.

32 Centers For Disease Control. Rubella prevention. Recommendations of the Immunization Practices Advisory Committee (ACIP). MMWR 1990; 39/No. RR-15.

33 Banatvala JE, Best JM. Rubella vaccines. In: Zuckerman AJ, ed. Recent developments in prophylactic immunization. Lancaster: Kluwer Academic Publishers, 1989, 155-80.

34 Schaffner W, Fleet WF, Kilroy AW, et al. Polyneuropathy following rubella immunization: a follow-up and review of the problem. Am J Dis Child 1974; 127: 684-8.

35 Freestone DS, Prydie J, Smith S, Hamilton G, Laurence G. Vaccination of adults with Wistar RA27/3 rubella vaccine. J Hyg $1971 ; 69: 471-7$.

36 Forrest JM, Honeyman MC, Lovric VA. Rubella vaccination and thrombocytopenia. Aust NZ J Med 1974; 4 : 352-5.

37 Tingle AJ, Allen M, Petty RE, Kettyls GD, Chantler JK. Rubella-associated arthritis. I. Comparative study of joint manifestations associated with natural rubella infection and RA27/3 rubella immunization. Ann Rheum Dis $1986 ; 45$ : 110-4.

38 Weibel RE, Stokes J, Buynak EB, Hilleman MR. Influence of age on clinical response to HPV-77 duck rubella vaccine. J Am Med Assoc 1972; 222 : 805-7.

39 Stokes J Jnr, Weibel RE, Buynak Eb, Hilleman MR. Clinical laboratory findings in adult women given HPV-77 rubella vaccine. International Symposium on rubella vaccines, London. Symp Series Immunobiol Stand 1968; 11: 415-22. Basel/New York: Karger.

40 Ogra PL, Herd JK. Arthritis associated with induced rubella infection. J Immunol 1971 107: 810-3.

41 Grayzel AI, Beck C. Rubella infection of synovial cells and the resistance of cells derived from patients with rheumatoid arthritis. J Exp Med 1970; 131:367-73.

42 Cunningham AL, Fraser JRE. Persistent rubella virus infection of human synovial cells cultures in vitro. J Infect Dis $1985 ; 151$ : 638-45.

43 Vergani D, Morgan-Capner P, Davies ET, Anderson AW, Tee DEH, Pattison JR. Joint symptoms, immune complexes and rubella. Lancet 1980; ii : 321-2.

44 Coyle PK, Wolinsky JS, Buimovici-Klein E, Moucha R, Cooper LZ. Rubella-specific immune complexes after congenital infection and vaccination. Infect Immun 1982; 36 : 498-503.

45 Singh VK, Tingle AJ, Schultzer M. Rubella-associated arthritis II. Relationship between circulating immune complex levels and joint manifestations. Ann Rheum Dis 1986; 45 : $115-9$.

46 Mims CA, Stokes A, Grahame R. Synthesis of antibodies, including antiviral antibodies, in the knee joints of patients with arthritis. Ann Rheum Dis 1985; 44: 734-7.

47 MacDonald H, Thompson KM, Tobin JO'H. Vaccination of women with the Cendehill strain of rubella virus. Practitioner $1971 ; 207: 57-66$.

48 Swartz A, Klingberg W, Goldwasser RA, Klinberg MA, Goldblum N, Hilleman MR. Clinical manifestations, according to age, among females given HPV-77 duck rubella vaccine. Am J Epidem 1971; 94 : 246-51.

49 Chantler JK, Ford DK, Tingle AJ. Persistent rubella infection and rubella-associated arthritis. Lancet 1982 i : 1323-5.

50 Tingle AJ, Chantler JK, Pot KH, Paty DW, Ford DK. Postpartum rubella immunization : association with development of prolonged arthritis, neurological sequelae, and chronic rubella viremia. J Infect Dis $1985 ; 152$ : 606-12.

51 Chantler JK, Tingle AJ, Petty RE. Persistent rubella virus infection associated with chronic arthritis in children. N Engl $\mathrm{J}$ Med 1985; 313 : 1117-22.

52 Banatvala JE, Best JM, O'Shea S, Dudgeon JA. Persistance of rubella antibodies after vaccination: detection after experimental challenge. Rev Infect Dis 1985; 7 (suppl 1): S86-90.

53 Best JM, Banatvala JE. Rubella. In: Zuckerman AJ, Banatvala JE, Pattison JR, eds. Principles and practice of clinical virology, 2nd ed. Chichester : John Wiley and Sons, 1990. $337-74$. 
54 Centers for Disease Control. Rubella vaccination during pregnancy. MMWR 1987; 36 : 457-61.

55 Banatvala JE, Druce A, Best JM, Al-Nakib W. Specific IgM responses after rubella vaccination - potential application following inadvertent vaccination during pregnancy. Br Med J 1977; 2: 1263-4.

56 Mortimer PP, Edwards JMB, Porter AD, Tedder RS, Haslehurst J. The immunoglobulin M response to rubella vaccine in young adult women. J Hyg $1984 ; 92$ : 277-83.

57 Meegan JM, Evans BK, Horstmann DM. Use of enzyme immunoassays and the latex agglutination test to measure the temporal appearance of immunoglobulin $\mathrm{G}$ and $\mathrm{M}$ antibodies after natural infection or immunization with rubella virus. $J$ Clin Microbiol $1983 ; 18$ : 745-8.

58 Enders G, Knotek F, Pacher U. Comparison of various serological methods and diagnostic kits for the detection of acute, recent, and previous rubella infection, vaccination and congenital infections. J Med Virol 1985 16: 219-32.

59 O'Shea S, Best JM, Banatvala JE, Shepherd WM. Development and persistance of classspecific serum and nasopharyngeal antibodies in rubella vaccines. J Infect Dis $1985 ; 151$ : 89-98.

60 Banatvala JE. Rubella vaccines. In: Waterson AP, ed. Recent advances in clinical virology. Edinburgh: Churchill Livingstone, 1977, 171-90.

61 Cusi MG, Rossolini GM, Cellesi C, Valensin PE. Antibody response to wild rubella virus structural proteins following immunization with RA27/3 live attenuated vaccine. Arch Virol 1988101 : 25-33.

62 Cusi MG, Metelli R, Valensin PE. Immune responses to wild and vaccine rubella viruses after rubella vaccination. Arch Virol $1989 ; 106: 63-72$.

63 Hillary IB, Griffith AH. Persistence of rubella antibodies 15 years after subcutaneous administration of Wistar 27/3 strain live attenuated rubella virus vaccine. Vaccine 1988 ; 2: 274-6.

64 Horstmann DM, Schluederberg A. Emmons JE, Evans BK, Randolph MF, Andiman WA. Persistence of vaccine-induced immune responses to rubella: comparison with natural infection. Rev Infect Dis 1985; 7 (suppl 1): S80-85.

65 Enders G, Nickerl L. Rubella vaccination: persistance of antibodies for 14-17 years and immune status of women with and without vaccination history. Immun Infect 1988; 16 : $58-64$.

66 O'Shea S, Woodward S, Best JM, Banatvala JE, Holzel H, Dudgeon JA. Rubella vaccination: persistence of antibodies for 10-21 years. Lancet 1988; ii: 909.

67 Just M, Just V, Berger R, Burkhardt F, Schilt U. Duration of immunity after rubella vaccination: A long term study in Switzerland. Rev Infect Dis 1985; 7 (suppl 1) : S91-3.

68 Chu SY, Bernier RH, Stewart JA, Herrmann KL, Greenspan JR, Henderson AK, Liang AP. Rubella antibody persistence after immunization. Sixteen year follow-up in the Hawaiian islands. J Am Med Assoc 1988; 259: 3133-6.

69 Hoshino M, Oka Y, Deguoji M, Hirajama M, Kono R. The ten year follow-up of the persistence of humoral antibody to rubella virus acquired by vaccination with the Japanese TO-336 vaccine. J Biol Stand $1982 ; 10: 213-9$.

70 Orenstein WA, Herrmann KL, Holmgreen P, et al. Prevalence of rubella antibodies in Massachusetts schoolchildren. Am J Epidemiol 1986; 124 : 290-4.

71 O'Shea S, Best JM, Banatvala JE, Marshall WC, Dudgeon JA. Rubella vaccination persistence of antibodies for up to 16 years. Brit Med J 1982; 285 : 253-5.

72 Ogra PL, Kerr-Grant D, Umana G, Dzierba J, Weintraub D. Antibody response in serum and nasopharynx after naturally acquired and vaccine-induced infection with rubella virus. N Engl J Med 1971; 285 : 1333-9.

73 Cradock-Watson JE, MacDonald H, Ridehalgh KS, Bourne MS, Vandervelde EM. Specific immunoglobulin responses in serum and nasal secretions after administration of attenuated rubella vaccine. J Hyg $1974 ; 73$ : 127-41.

74 Inouye S, Kono R, Takeuchi Y. Oligomeric immunoglobulin A antibody response to rubella virus infection. J Clin Microbiol 1978; 8: 1-6.

75 Honeyman MC, Forrest JM, Dorman DC. Cell-mediated immune response following natural rubella and rubella vaccination. Clin Exp Immunol 1978; 17 : 665-71. 
76 Rossier E, Phipps PH, Polley JR, Webb T. Absence of cell-mediated immunity to rubella virus 5 years after rubella vaccination. Can Med Assoc J 1977; 116: 481-4.

77 Buimovici-Klein E, Cooper LZ. Cell-mediated immune response in rubella infections. Rev Infect Dis 1985; 7 (suppl 1): S123-8.

78 Brandling-Bennett AD, Jackson RS, Halstead SB, et al. Serologic response to revaccination with two rubella vaccines. Am J Dis Child 1976; 130 : 1081-4.

79 Plotkin SA, Farquhar JD, Ogra PL. Immunologic properties of RA27/3 rubella virus vaccine. J Am Med Assoc 1973; 225 : 585-90.

80 Vãånånen $\mathrm{P}$, Makela $\mathrm{P}$, Vaheri A. Effect of low level immunity on response to live rubella virus vaccine. Vaccine $1986 ; 4: 5-8$.

81 O'Shea S, Best JM, Banatvala JE, Marshall WC, Dudgeon JA. Persistence of rubella antibody 8 to 18 years after vaccination. Brit Med J 1984; 288 : 1043.

82 Serdula MK, Halstead SB, Wiebenga NH, Herrmann KL. Serological response to rubella revaccination. J Am Med Assoc 1984; 251 : 1974-7.

83 PHLS Working Party. Summary of the recommendations of the PHLS Working Party on the laboratory diagnosis of rubella. Microbiol Digest $1988 ; 5: 49-51$.

84 O'Shea S, Best JM, Banatvala JE. Viremia, virus excretion and antibody responses after challenge in volunteers with low levels of antibody to rubella virus. J Infect Dis $1983 ; 148$ : $639-47$.

85 Morgan-Capner P, Hodgson J, Hamblin MH, et al. Detection of rubella specific IgM in subclinical rubella reinfection in pregnancy. Lancet 1985 ; i : 244-6.

86 Schiff GM, Young BC, Stefanovic GM, et al. Challenge with rubella virus after loss of detectable vaccine-induced antibody. Rev Infect Dis 1985; 7 (suppl 1): S157-63.

87 Morgan-Capner P. Does rubella reinfection matter? In: Mortimer PP, ed. Public health virology, 12 reports. London: Public Health Laboratory Service, 1986, 50-62.

88 Best JM, Banatvala JE, Morgan-Capner P, Miller E. Fetal infection after maternal reinfection with rubella: criteria for defining reinfection. Brit Med J 1989; 299: 773-5.

89 Das BD, Lakhani P, Kurtz JB, et al. Congenital rubella after previous maternal immunity. Arch Dis Child $1989 ; 65: 545-6$.

90 Dimmock NJ, Griffiths PD, Madeley CR, eds. Control of virus diseases. Cambridge: Cambridge University Press, 1990.

91 Zuckerman AJ, ed. Recent developments in prophylactic immunization. Lancaster: Kluwer Academic Publishers, 1989.

92 Terry GM, Ho-Terry L, Londesborough P, Rees KR. Localization of the rubella E1 epitope. Arch Virol 1988; 98 : 189-97.

93 Lozzi L, Rustici M, Corti M, et al. Structure of rubella E1 glycoprotein epitopes established by multiple peptide synthesis. Arch Virol 1990; 110: 271-6.

94 Ho-Terry L, Cohen A, Londesborough P. Rubella virus wild-type and RA27/3 strains : A comparison by polyacrylamide-gel electrophoresis and radioimmune precipitation. $J$ Med Microbiol $1982 ; 15$ : 393-8.

95 Dorsett PH, Miller DC, Green KY, Byrd FI. Structure and function of the rubella virus proteins. Rev Infect Dis 1985; 7 (suppl 1): S150-6.

96 Dominquez G, Wang C, Frey T. Sequence of the genome RNA of rubella virus: Evidence for genetic rearrangement during togavirus evolution. J Virol $1990 ; 177$ : 225-38.

97 Nakhasi H, Meyer B, Liu T. Rubella virus cDNA, sequence and expression of E1 envelope protein. J Biol Chem 1986; 261 : 16616-21.

98 Clarke DM, Loo T, Hu I, Chong P, Gillam S. Nucleotide sequence and in vitro expression of rubella virus $24 \mathrm{~S}$ subgenomic messenger RNA encoding the structural proteins $\mathrm{E}_{1} \mathrm{E}_{2}$ and C. Nucleic Acids Res 1987; 15 : 3041-57.

99 Mazancourt A, Perricaudet M. Expression of rubella virus cDNA encoding the E1 structural protein. Biochimie 1989; $71: 681-5$.

100 Oker-Blom C, Pettersson R, Summers M. Baculovirus polyhedrin promoter-directed expression of rubella virus envelope glycoproteins, E1 and E2, in spodoptera frugiperda cells. Virology $1989 ; 172$ : 82-91.

101 Terry G, Ho-Terry L, Londesborough P, Rees KR. A bio-engineered rubella E1 antigen. Arch Virol 1989; 104 : 63-75. 